\title{
Refocusing ecosystem services towards sustainability
}

\author{
Matthias Schröter ${ }^{\mathrm{a}, \mathrm{b}, \mathrm{c}, *}$, Klara H. Stumpf ${ }^{\mathrm{d}}$, Jacqueline Loos $^{\mathrm{e}}$, Alexander P.E. van Oudenhoven ${ }^{\mathrm{f}, \mathrm{c}}$, \\ Anne Böhnke-Henrichss ${ }^{\mathrm{c}, \mathrm{g}}$, David J. Abson ${ }^{\mathrm{h}}$
}

\author{
${ }^{a}$ Department of Ecosystem Services, UFZ - Helmholtz Centre for Environmental Research, Permoserstr. 15, 04318 Leipzig, Germany \\ ${ }^{\mathrm{b}}$ German Centre for Integrative Biodiversity Research (iDiv) Halle-Jena-Leipzig, Deutscher Platz 5e, 04103 Leipzig, Germany \\ ${ }^{\mathrm{c}}$ Environmental Systems Analysis Group, Wageningen University, P.O. Box 47, 6700 AA Wageningen, The Netherlands \\ ${ }^{\mathrm{d}}$ Norbert Elias Center for Transformation Design and Research, Europa-University Flensburg, Auf dem Campus 1, 24943 Flensburg, Germany \\ e Agroecology, Department of Crop Science, Georg-August University Göttingen, Grisebachstr. 6, 37077 Göttingen, Germany \\ ${ }_{\mathrm{f}}^{\mathrm{f}}$ Institute of Environmental Sciences CML, Leiden University, Einsteinweg 2, 2333 CC Leiden, The Netherlands \\ ${ }^{\mathrm{g}}$ Landscape Management Group, University of Potsdam, Karl-Liebknecht-Str. 24-25, 14476 Potsdam, Germany

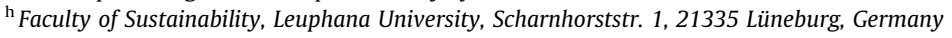

\section{A R T I C L E I N F O}

Article history:

Received 22 June 2016

Received in revised form 7 March 2017

Accepted 18 March 2017

Available online 27 March 2017

\section{Keywords:}

Distributive justice

Intergenerational justice

Intragenerational justice

Procedural justice

Sustainable development

\begin{abstract}
A B S T R A C T
Ecosystem services and sustainability have become prominent concepts in international policy and research agendas. However, a common conceptual ground between these concepts is currently underdeveloped. In particular, a vision is missing on how to align ecosystem services with overarching sustainability goals. Originally, the ecosystem service concept focused on sustaining human well-being through biodiversity conservation. Nevertheless, studies within the field also consider appropriation beyond carrying capacities, and natural resource management that involves environmentally damaging inputs as ecosystem service provision. This brings the ecosystem service concept into conflict with the core goal of sustainability, i.e. achieving justice within ecological limits over the long term. Here, we link the ecosystem service concept to sustainability outcomes operationalized in terms of justice. Our framing positions sustainability as an overarching goal which can be achieved through seven key strategies: equitable (1) intergenerational and (2) intragenerational distribution, (3) interspecies distribution, (4) fair procedures, recognition and participation, (5) sufficiency, (6) efficiency, and (7) persistence. Applying these strategies has the potential to re-focus the ecosystem service concept towards the normative goal of sustainability. We identify research needs for each strategy and further discuss questions regarding operationalization of the strategies.
\end{abstract}

(c) 2017 Elsevier B.V. All rights reserved.

\section{Introduction}

Ecosystem services and sustainability can both be defined as descriptive and normative scientific concepts. They are used to describe and analyse the relationship between humans and the environment (Abson et al., 2014; Gómez-Baggethun et al., 2010). The normative aspect of both concepts expresses how the relationship between human societies and their environment should be shaped. Next to their use in descriptive and analytical science, both concepts can also involve value judgements and norms.

\footnotetext{
* Corresponding author at: Department of Ecosystem Services, UFZ - Helmholtz Centre for Environmental Research, Permoserstr. 15, 04318 Leipzig, Germany.

E-mail addresses: matthias.schroeter@idiv.de (M. Schröter), klara.stumpf@ uni-flensburg.de (K.H. Stumpf), jloos@gwdg.de (J. Loos), a.p.e.van.oudenhoven@ cml.leidenuniv.nl (A.P.E. van Oudenhoven), anne.boehnke-henrichs@wur.nl (A. Böhnke-Henrichs), abson@leuphana.de (D.J. Abson).
}

Commonly, ecosystem services describe the ecological structures and functions appropriated as a means to increase human well-being (Haines-Young and Potschin, 2010a). The ecosystem service concept is a boundary object that illustrates the relationship between humans and their natural environment (Abson et al., 2014; Schröter et al., 2014b). The concept assigns instrumental value to ecological structures and functions, based on the extent to which they enhance human well-being. In other words, the ecosystem services notion contends that ecosystems should be conserved because to do so is also 'good' for humans. Currently, research on ecosystem services implements a rather descriptive understanding of ecosystems' contributions to human well-being and often disregards normative questions, such as the well-being of future generations (van den Belt and Stevens, 2016) and how to achieve social and environmental justice (Jacobs et al., 2016). Here, we shed light on these questions by situating ecosystem 
services within the broader, normative concept of sustainability that focuses on human well-being (e.g. Kuhlman and Farrington, 2010). Sustainability has been defined in many different ways. A widely shared foundation, which we adopt for this paper, is that sustainability represents an ideal, non-fixed state that meets human needs of current and future generations within ecological limits (WCED, 1987).

Originally, the ecosystem service concept called attention to the consequences of biodiversity loss for future human well-being and was thus closely linked to sustainability (MA, 2005). Early notions of ecosystem services argued that fighting biodiversity loss should take place because biodiversity contributes to essential services that ecosystems provide (Ehrlich and Ehrlich, 1981; Ehrlich and Mooney, 1983). Links between ecosystem services and sustainability are also implied by their co-occurrence in research and policy agendas, such as the Aichi Targets of the Convention on Biological Diversity (UNEP, 2010), the Sustainable Development Goals (UN, 2012) and the Intergovernmental Platform on Biodiversity and Ecosystem Services (IPBES) (Díaz et al., 2015). This co-occurrence suggests that the ecosystem service concept can, or at least is intended to, contribute to sustainable ecosystem management (Bennett et al., 2015; Jacobs et al., 2013). However, various examples demonstrate that the application of the ecosystem service concept potentially conflicts with sustainability goals. We illustrate and elaborate some of these examples from recent literature on ecosystem services.

Despite some advancements to define and operationalize the ecosystem service concept (Boyd and Banzhaf, 2007; HainesYoung and Potschin, 2013; TEEB, 2010), definitions remain ambiguous and open to different interpretations (Danley and Widmark, 2016; Nahlik et al., 2012). This ambiguity allows different users to creatively apply the concept (Schröter et al., 2014b). However, some interpretations may place the ecosystem service concept at odds with its original discursive and normative framings. For instance, some studies have labelled intensive, nonrenewable natural resource use as 'ecosystem services', such as lignite mining (Burkhard et al., 2012), peat extraction (UK NEA, 2011), and intensive animal husbandry and intensive crop production (Raudsepp-Hearne et al., 2010). Moreover, overuse of provisioning services can conflict with sustainability goals. As an example, large-scale intensive fishing above maximum sustainable yield is a global threat to marine ecosystems (Halpern et al., 2008; Pauly et al., 1998). Total landings are frequently used to quantify the ecosystem service provision 'food' (for a review cf. Liquete et al., 2013), regardless of how sustainable those landings may be. Overall, ecosystem service studies regularly consider food production within a set of assessed services (Lautenbach et al., 2015; Malinga et al., 2015). Intensive agricultural practices, however, can put regulating and cultural services at risk (Lee and Lautenbach, 2016; Power, 2010). In practice, value judgements based solely on an operationalization of the ecosystem service concept might conflict with value judgements based on the concept of sustainability. For instance, when ecosystem service assessments produce aggregated values, these tell little about inter- and intragenerational distribution of ecosystem services and the values attached to them. Intra- and intergenerational distributions are, however, important elements of sustainability (WCED, 1987), as we will explain in more detail below.

Despite calls for more consideration of sustainability in ecosystem service appropriation and management (Daly, 1992; Jacobs et al., 2013; Norgaard, 2010), an understanding of the common ground between ecosystem services and sustainability is currently underdeveloped. A common vision is lacking on how to (re)align the conceptualization and management of ecosystem services with sustainability as an overarching normative goal (Bennett et al., 2015; Loos et al., 2014).
In this paper, we embed the ecosystem service concept within a sustainability framework in order to operationalize normative judgements of ecosystems' contributions to human well-being. If the ecosystem service concept is to be understood as a means to analyse, deliberate and manage society-environment interactions, then the notion of sustainability would provide a wellestablished and flexible framework for normatively grounding that understanding. In order to develop a conceptual framework that refocuses the ecosystem service concept towards sustainability, we explore seven sustainability strategies that could be considered for the assessment, governance and management of ecosystems services. For each sustainability strategy, we suggest ways to advance future ecosystem service assessments and management.

\section{A framework for conceptualizing ecosystem services for sustainability}

We present a framework that connects five aspects of ecosystem service appropriation to four sustainability outcomes through seven key sustainability strategies (Fig. 1).

Five aspects of ecosystem service appropriation can be distinguished based on earlier conceptualisations of the ecosystem service framework, also described as the 'cascade model' (HainesYoung and Potschin, 2010b; TEEB, 2010). According to this model, which has been further developed by, among others, Villamagna et al. (2013), (i) Ecosystem properties are a "set of ecological conditions, processes and structures" (van Oudenhoven et al., 2012) from which ecosystem services are appropriated. (ii) Capacities are the potential of the social-ecological system's available ecosystem properties to sustainably provide ecosystem services (Villamagna et al., 2013). (iii) Flows are the actually appropriated ecosystem services (Schröter et al., 2014a). (iv) Benefits gained from that ecosystem service appropriation differ from the services as they refer to positive changes in different aspects of human well-being (Naeem et al., 2016), such as safety, leisure, happiness, health and welfare (Schmidt et al., 2016). (v) People can hold different values in relation to well-being, i.e. different measures of importance (Chan et al., 2012). Aspects (i) and (ii) relate to the potential to achieve human well-being through ecosystem service appropriation and (iii), (iv) and (v) relate to human well-being derived from actual appropriation of ecosystem services.

The right-hand side of our framework (Fig. 1) presents four aspects of justice as sustainability outcomes. Central to sustainability are equal rights of present and future generations to the prerequisites of a good human life (e.g. Ott, 2003). To achieve such distributive justice, ecosystem services would have to be used within ecological limits so that ecosystems can provide the conditions for human well-being over the long term. This differs from the conceptualization of natural capital and 'strong sustainability', which has been used earlier in the context of ecosystem services (Ekins et al., 2003). Strong sustainability assumes that nondeclining natural capital is a necessary condition for achieving human well-being over time (Neumayer, 2010). Taking a more consequential position, we focus on the outcomes resulting from the interaction between natural capital, different other forms of capital (labour, knowledge, technology) and socio-political contexts (Palomo et al., 2016; Remme et al., 2014; van Oudenhoven et al., 2015). In parallel to distributive justice, sustainability also entails procedural justice, including fair treatment, recognition and participation in societal decisions (Agyeman and Evans, 2004; Schlosberg, 2004). While being a normative goal in itself, procedural justice may also help to ensure that rights and values of different interest groups are acknowledged and considered when it comes to fair distribution of benefits. Furthermore, as sustainability is a notion that is open to different interpretations, it 


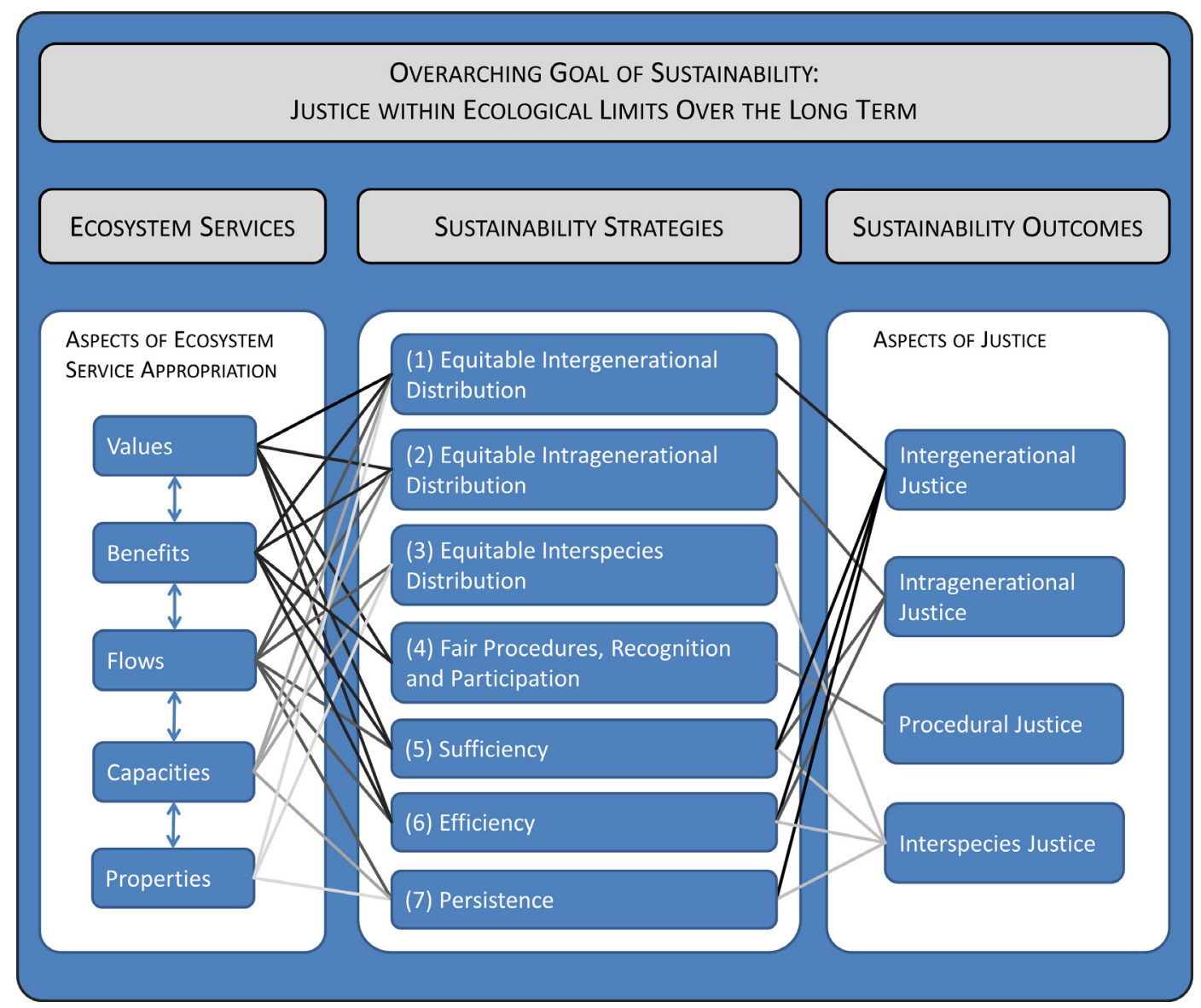

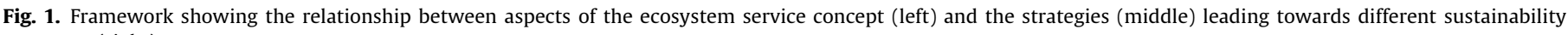
outcomes (right).

requires participation to be defined in a given context (Piso et al., 2016). Given the multiple contexts in which ecosystem services are appropriated and the multiple, potentially conflicting goals to which the management of that appropriation is aligned, a focus on procedural justice provides an explicit platform for more discursive aspects of the ecosystem service concept. The anthropocentric perspective of sustainability can be complemented by incorporating justice towards non-human entities, for instance towards other species (Norton, 2005). Consideration of interspecies justice originates from a perceived narrow focus on anthropocentric values within the sustainability debate (Costanza, 1989; Lockwood, 1999) and comprises equal consideration of all species in the consequences of societal actions (Davidson, 2013). Sustainability thus comprises justice-related (intergenerational, intragenerational, procedural and interspecies) sub-goals constrained by ecological conditions over time.

We distinguish seven key sustainability strategies (Fig. 1). These strategies can be understood as 'filters' through which the appropriation of ecosystem services is to pass in order to ensure contribution to sustainability outcomes. The application of these 'filters' can be used to analyse whether the appropriation of an ecosystem service is sustainable (cognitive goal). Furthermore, such information could enter societal discourses about where and how the appropriation of ecosystem services could match the overarching societal aim of sustainability. The 'filters' can then also be used to guide and structure management decisions in order to reach sustainability (normative goal). The seven strategies are: 1. Equitable intergenerational distribution; 2. Equitable intragenerational distribution; 3. Equitable interspecies distribution; 4. Fair procedures, recognition and participation; 5. Sufficiency; 6. Efficiency; 7. Persistence. Note that the order of the strategies does not reflect a ranking of importance, as the strategies are interlinked means towards sustainability. For instance, equitable distribution of benefits derived from ecosystem services over the long term simultaneously requires a successful strategy to stay within ecological limits. The first three strategies address distributive aspects. Fair procedures, recognition and participation focuses on processes in relation to the first three strategies. Sufficiency, efficiency and persistence relate to means to handle ecological limits.

In the following sections we reflect on each of the seven sustainability strategies and exemplify how the strategies can be pursued when operationalizing the ecosystem service concept in the context of the overarching goal of sustainability.

\section{Strategies to link ecosystem services and sustainability}

\subsection{Equitable intergenerational distribution}

The question of how benefits and values derived from ecosystem services are distributed between current and future generations relates to inter- and intragenerational justice. Ecosystem properties and resulting capacities need to be maintained, and the societal capability to appropriate those properties needs to be ensured. This would ensure that current and future generations can derive flows of ecosystem services, and therefore benefits from their interactions with ecosystems according to their values. However, future generations might desire different ecosystem services 
than current generations (Costanza, 2000). While we currently cannot know the preferences of future generations, maintaining ecosystem properties maintains options for future generations to benefit from different flows of ecosystem services. This prerequisite to providing services over time is in line with strong sustainability (Ekins et al., 2003; Neumayer, 2010). The less tangible benefits derived from human interactions with nature (e.g. sense of place, psychological well-being) are strongly related to traditional practices and cultural ecosystem services (cf. Louv (2005), Raymond et al. (2013)). The loss of such traditions and experiences-also referred to as the extinction of experience (e.g. Miller, 2005)-has been associated with a number of negative outcomes for sustainability and has led to calls for reconnections to nature (Abson et al., 2017). Hence, a better understanding of how certain cultural ecosystem services could contribute to achieving the overarching goal of sustainability is needed. Moreover, option, existence and bequest values express people's appreciation of the continued existence of species and ecosystems beyond their immediate use (Chan et al., 2012; Klain et al., 2014). As these values relate strongly to conservation of species and ecosystems over time, a better recognition in ecosystem service assessments could ensure that intergenerational aspects are considered (Chan et al., 2016).

This discussion of equitable intergenerational distribution implies that three key issues need to be addressed in future ecosystem service assessments: 1) Account for potential liquidation of natural capital (which would be detrimental to intergenerational justice) in assessments of benefits. 2) Assess how ecosystem service flows maintain and support (or damage and impair) the long-term capacity of the social-ecological system. 3) Integrate option, existence and bequest values into ecosystem service assessments.

\subsection{Equitable intragenerational distribution}

Intragenerational distribution relates to the question of which members of present generations benefit from ecosystem services and how people value the appropriated flows. Depending on socio-political and other factors, access to ecosystem service flows can be distributed unequally (Lakerveld et al., 2015). Hence, evaluating intragenerational justice requires an assessment of the distribution of the costs and benefits of ecosystem service appropriation for different beneficiaries, which goes beyond simply aggregating values of ecosystem services (Bennett et al., 2015). Ecosystem service governance and management could be improved by assessing who actually receives flows of ecosystem services, who misses out and how land management satisfies needs of different societal groups for ecosystem services (e.g. Milcu et al., 2014). A distinction between the capacities to provide services and the actual flows (including an assessment of who benefits) can help to elucidate aspects of intragenerational justice in ecosystem service assessments. Inequitable intragenerational distribution might result from trade-offs between ecosystem services, i.e. situations in which the provision of one service increases at the expense of another service (Bennett et al., 2009). This can also involve a shift from many service beneficiaries to few. For instance, plantations for maximizing timber or palm oil production or carbon sequestration may conflict with conserving structurally rich and diverse forests (Duncker et al., 2012) from which people can collect wild foods, other non-timber forest products or enjoy cultural ecosystem services (Dislich et al., 2016). A meaningful ecosystem service assessment needs to untangle the potential trade-offs in ecosystem service flows and associated benefits and values of different people. As people ascribe different values to the same ecosystem services (Chan et al., 2012) and have different degrees of power to express their interests (Berbés-Blázquez et al., 2016; Sikor et al.,
2013), operationalizing intragenerational distribution within the ecosystem service concept requires recognizing and accounting for a wider plurality of values that are not generally considered in present ecosystem service assessments (Iniesta-Arandia et al., 2014; Jacobs et al., 2016).

Only few notable exceptions have demonstrated the intragenerational distribution of benefits derived from ecosystem services between stakeholder groups (Daw et al., 2011; Lakerveld et al., 2015). Recently, more attention has been paid in the ecosystem service literature to the importance of values ascribed to services by different stakeholders (e.g., Daw et al., 2015; Iniesta-Arandia et al., 2014; Klain et al., 2014). The field of ecosystem services has also begun to address issues of equity and environmental justice (Aragão et al., 2016; Ernstson, 2013; Jacobs et al., 2016; McDermott et al., 2013) suggesting a shift back to the discursive roots of the ecosystem service concept.

The discussion of equitable intragenerational distribution implies that future ecosystem service assessments and management need to address the following issues: 1) A greater focus on the multiple (bundled) services that flow from specific ecosystems, rather than (maximized) individual services. 2) Acknowledge potential inequalities between different actors in ecosystem service appropriation and assess disaggregated benefits and values. 3) Explicit concern for power relations in the ecosystem service framework, particularly with regard to individuals' and cultural groups' capabilities to access service flows.

\subsection{Equitable interspecies distribution}

Appropriating ecosystem services can have negative effects on ecosystems and thus on species that are either directly used as ecosystem services, or suffer from use of other ecosystem services. Examples are the extractive use of wood from forests, overfishing oceans or overgrazing rangelands. Including interspecies justice within the overarching goal of sustainability, one needs to determine the 'just' proportion of human appropriation of ecosystem services. This 'just' proportion includes ecosystem capacity and flows left for other species, even if - considering the anthropocentric focus of the ecosystem service concept - the capacity and flow left for other species are no 'ecosystem services' for these species. A way to conceptualize this for provisioning services would be by considering the ecosystem service flow appropriated by humans in relation to the 'just' claims of other species. An example is wood production in a forest. Capacity could be conceptualized as the annual regrowth, and flow as the annual harvest. In a parsimonious way, sustainability could be defined as flow not exceeding capacity (Schröter et al., 2014a). However, concerning interspecies distribution, the question arises how much of the biomass should be left to other species that also depend on it. Similarly, recreation experience (as a cultural ecosystem service) may be increased through modifying ecosystems, for example through replacing seminatural habitats by parks with uniform grass cover to increase their aesthetic appeal. However, such management may have detrimental impacts on biodiversity that are not considered in the assessment of cultural ecosystem service provision.

Based on this discussion of equitable interspecies distribution, the following issues in future ecosystem service assessment and management should be addressed: 1) Explicit consideration of the capacity of a particular ecosystem to provide flows of ecosystem services and balance human needs and wants with biodiversity conservation. 2) Consideration of the ecological impacts of ecosystem service appropriation on ecosystem properties. 3) Acknowledgment that ecosystems are not only of instrumental values to humans, but are also ascribed intrinsic value for the biodiversity they contain. 


\subsection{Fair procedures, recognition and participation}

Sustainability concerns include procedural justice, which involves recognition, participation and power. Stakeholder involvement allows different people to ascribe values to different ecosystem services and to decide on how they should be assessed (e.g. Castro et al., 2014). This helps to 'unpack' aspects of procedural justice. At the same time, including stakeholders in assessments may be a first step towards participatory ecosystem service governance and management, which contributes to procedural justice. Group deliberation and public debate have been proposed to articulate values of public goods such as clean water and air (Wilson and Howarth, 2002). Such deliberation addresses value plurality among stakeholders, assesses how these values could change over time, and reflects on the socio-economic costs of appropriating certain ecosystem services (Kosoy and Corbera, 2010).

The ecosystem service concept offers a platform to represent different values of and interests in using ecosystems (Justus et al., 2009; Schröter et al., 2014b). This platform could provide a basis for participatory decision processes on sustainable use of ecosystem services and therefore contribute to procedural justice. However, critical reflection is required on whether power relations prevent some stakeholders from expressing and claiming their values and interests (Felipe-Lucia et al., 2015). Moreover, the framing in terms of ecosystem services may discriminate against other ways of knowing and other framings of nature-society relations (Sikor et al., 2013).

Based on this discussion of procedural justice, future ecosystem service assessments and management should: 1) Move beyond simply assessing the benefits appropriated from societal interactions with ecosystems and study the procedures by which ecosystem services are appropriated and the extent to which such procedures are inclusive and just. 2) Directly address power, inclusivity and participation in ecosystem service assessment and management. 3) Emphasize the pluralistic values ascribed to societynature interactions and consider how such values can be part of the ecosystem service framework.

\subsection{Sufficiency}

By asking "how much is enough?" (Sachs and Santarius, 2007, p. 160) rather than "how much more can be extracted?", sufficiency offers an awareness-raising perspective on the human dependency on ecosystems. Sufficiency relates ecosystem service flows to different aspects of distributive justice and asks for absolute quantities of ecosystem services that are necessary for meeting the needs of present and future generations. A change in value perceptions and preferences can change the proportions of ecosystem services appropriated from ecosystems and reduce overuse. For instance, sufficiency might lead to reduced fodder extraction for meat production (provisioning services), which could pave the way for increasing non-material benefits of cultural or regulating services from restored ecosystems (Benayas et al., 2009; Power, 2010). Thus, sufficiency might reduce the flow of provisioning services extracted from nature to a level that ensures the capacity of an ecosystem to provide other services (see also section 4.7).

This discussion on sufficiency implies that there is a need to: 1) Operationalize the ecosystem service flows necessary for achieving human well-being within explicitly defined ecological limits (e.g., Daly, 1992; Steffen et al., 2015). This may involve explicit quantification of the ecological carrying capacity of a given ecosystem beyond which appropriated ecosystem service flows are not sustainable. 2) Explicitly acknowledge that maximizing ecosystem services benefits should not be the goal of managing societyenvironment interactions.

\subsection{Efficiency}

Efficiency means non-wasteful use of resources for satisfying human needs (Baumgärtner et al., 2012), which may reduce pressure on ecosystems by diminishing ecosystem service flows. Two types of efficiency are resource use and allocative efficiency. Resource use efficiency refers to reducing "the use of materials and energy per unit of goods and services" (Sachs and Santarius, 2007, p. 158). However, marginal increases in efficiency can lead to higher aggregated appropriation in ecosystems due to rebound effects (Alcott, 2005). Hence, resource use efficiency is an ambivalent strategy for sustainability. Allocative efficiency refers to allocating scarce resources to their best societal use (Daly, 1992). Wasteful use of ecosystem services can be seen as a market failure. This failure could, in classical economic theory, be adjusted by assigning monetary values to ecosystem services and subsequently correcting market prices. Marginal monetary values should then reflect scarcity and uncertainty about tipping points that could be crossed by increased use of a service (Fisher et al., 2008). Of all sustainability strategies, allocative efficiency relates most closely to monetary valuation and hence to the way a large part of the literature implicitly conceptualizes and explicitly operationalizes ecosystem services. Monetary valuation can help to more efficiently allocate multiple cultural and regulating services that are lost by conversion of or gained through investment in ecosystems. However, monetary valuation implies that a single commensurable metric can be applied to all ecosystem services (Abson and Termansen, 2011), which is problematic for the recognition of pluralistic values ascribed to ecosystem services (Chan et al., 2012; Díaz et al., 2015; Klain et al., 2014). Moreover, typical valuation approaches are premised on the ability to pay and aggregate utility maximization, which ignores the initial allocation of money and consequently distributive issues.

Based on this discussion of efficiency, two key aspects for future ecosystem service assessments and management are recommended: 1) Efficiency is only a meaningful strategy in relation to a primary normative goal, such as justice (Baumgärtner et al., 2012). This contrasts to treating efficiency as an inherent goal, as is often done in economics. 2) If efficiency is considered, it should be done across long time horizons rather than on static assessments.

\subsection{Persistence}

Intergenerational justice presupposes persistence of ecosystem properties over time. Within this context we first discuss the consistency principle, which is often advocated in the sustainability discourse, before we shortly address the more overarching concept of resilience of social-ecological systems.

Persistence requires economic processes to be synchronized with ecological processes and time frames. This alignment is called the consistency principle (Sachs and Santarius, 2007). A practical example of the consistency principle implies that the economic production system should release only as much waste in a given time frame as regulating services can recycle or absorb within that time frame. Thus, persistence limits the flow of ecosystem services to the capacity of ecosystems to generate matter, energy and information which can be renewed within human time frames (Daly, 1977). Consistency thus entails a comparison of ecosystem service capacity and flow, which is a parsimonious way to measure sustainability (Schröter et al., 2014a). Flows that exceed these levels entail degrading ecosystem services quantity and quality for future generations. The absolute scale of permissible societal activities is therefore relative to the capacity of the ecosystem to absorb and renew (Daly, 1992). This criterion excludes coal, gas and peat as sustainably appropriable ecosystem services. Consistency further- 
more gives guidance on how sustainably services are appropriated. Many ecosystem services are co-produced as a combination of different capital inputs (Fisher et al., 2008). For instance, conventional agricultural crop production uses non-renewable resources, such as phosphorous or fossil fuels, or involves the liquidation of potentially renewable natural capital stocks (e.g. soil nutrient mining). The use of fertilizers and pesticides provide examples of capital input where economic and ecological production cycles are not aligned. If the use of these inputs contradicts the consistency principle, then sustained ecosystem service provision for future generations is at stake. Thus, in order to evaluate the sustainability of ecosystem service flows, capital inputs need to be integrated in ecosystem service assessments (Palomo et al., 2016).

Because provisioning services depend on stocks (i.e. ecosystem properties), renewability and consistency are more apparent for provisioning services than for regulating and cultural services. Persistence of regulating and cultural services is better expressed through the maximum carrying capacity and resilience of socialecological systems (Ekins et al., 2003). Resilience can be defined as the capacity of a system to retain its identity in face of disturbance (Walker et al., 2006). In an ecosystem service context, this identity is the property of a social-ecological system to sustain the provision of services (Biggs et al., 2012). An example could be the maximum number of tourists that are allowed to enter an area without causing disturbances that the ecosystem cannot absorb without changing its principle function and character.

To better consider persistence, the following issues should underpin future ecosystem service assessment and management: 1) Acknowledge that ecosystems are dynamic and consider temporal ecosystem dynamics, potential regime shifts and long term degradation of ecosystem properties. 2) Identify to what extent the appropriation of benefits from ecosystems are dependent on non-renewable inputs and how this influences the long term persistence of the flows of ecosystem services.

\section{Open questions on operationalising links between ecosystem services and sustainability}

Depending on the problem at hand, our framework allows three alternative entry points, which emphasize the reciprocal relationship between ecosystem services and sustainability. These entrypoints are: (1) an ecosystem service perspective; (2) a sustainability strategies perspective; and (3) a sustainability outcomes perspective (Fig. 2). For each of these entry points, the framework assists in addressing different questions related to the interface of ecosystem services and sustainability. These questions include, for instance: Which aspects of ecosystem service appropriation can affect the achievement of a particular sustainability outcome? Which aspects of ecosystem service appropriation are shaped by a particular sustainability strategy? Which sustainability strategies are relevant for an ecosystem service assessment to contribute towards sustainability?

Many questions remain with regard to the attempt to link ecosystems services and sustainability. These questions relate to descriptive-analytical problems for scientific assessments and to normative-deliberative problems for deliberative discourses. Furthermore, practical problems related to management implementation arise, which we do not cover here.

Scientific assessments require tools to analyse the different strategies properly, for example through appropriate indicators for the sustainability outcomes (Moldan et al., 2012; Naeem et al., 2016; Smith et al., 2013). This is particularly challenging as an understanding of sustainability (as an ideal, non-fixed and deliberated state) differs between places. This emphasises the need

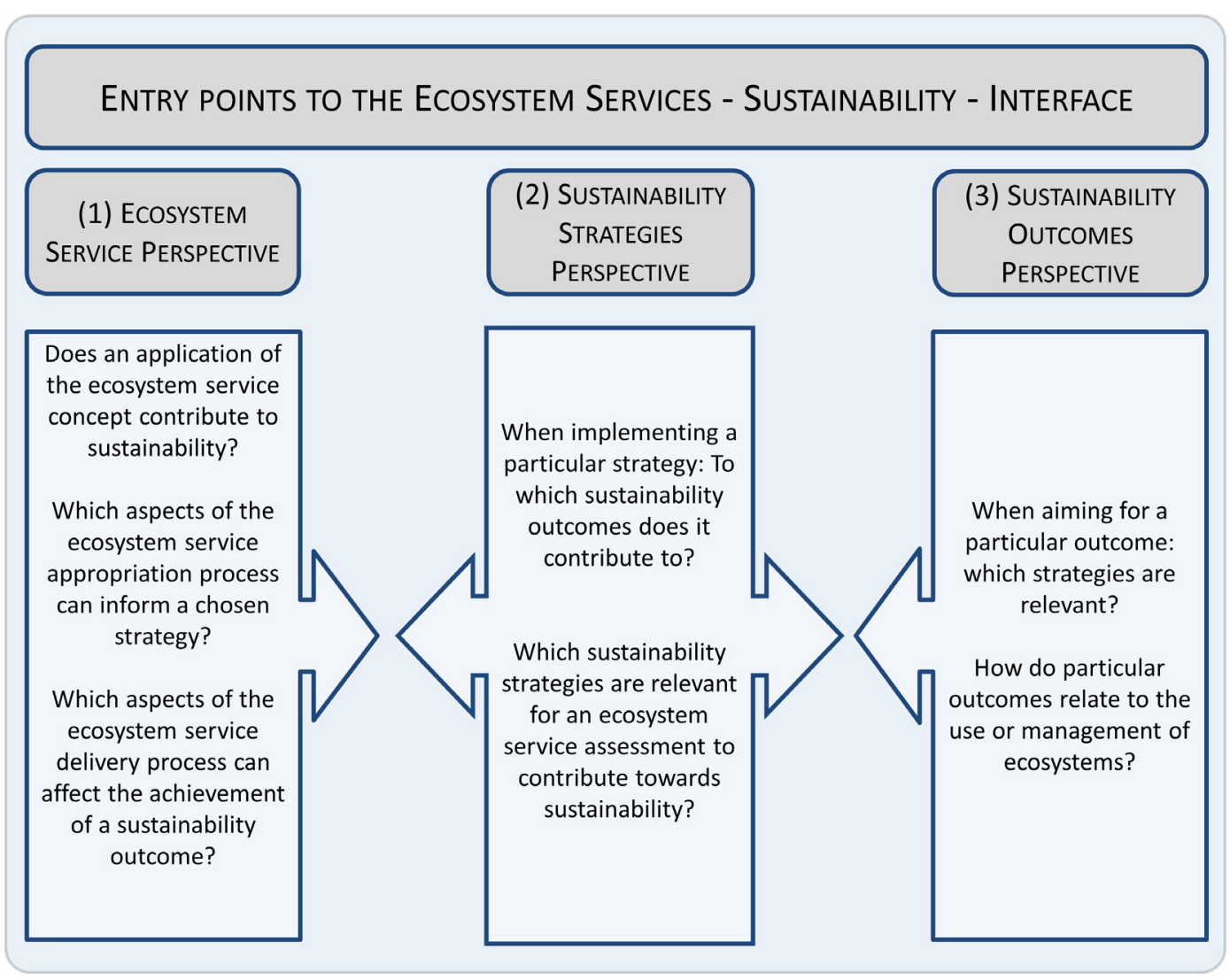

Fig. 2. Different entry points to the ecosystem service-sustainability-interface. 
for fair procedures and recognition when deliberating what should be sustained concerning ecosystem service use. In an interconnected world, decisions to manage ecosystems in one place can affect the sustainability of ecosystem use in other places (Kissinger et al., 2011; Liu et al., 2015). Hence, while place-based assessments in the context of ecosystem services and sustainability are important (Potschin and Haines-Young, 2013; Wu, 2013) there is also the need to consider telecouplings and interregional flows of ecosystem services between regions (Liu et al., 2016).

Even integrated scientific assessments will struggle to address all strategies at once. Open questions also remain regarding the interlinkages between the strategies proposed in this paper. For instance, equitable intergenerational distribution requires sufficiency, efficiency and persistence, as these strategies ensure that human activities stay within ecological limits. Another example are the interlinkages between the allocative efficiency strategy and other strategies. When aiming for allocative efficiency, questions may arise such as: How is the best societal use determined that should be efficiently met? How to delimit a societal system, in particular in face of telecouplings? Are uncertainty and scarcity actually reflected in monetary values? Hence, a thorough consideration of other sustainability strategies is required to answer these questions.

The conceptual links between ecosystem services and sustainability can inform discourses within society, at the sciencesociety interface and within science. Based on deliberated goals, well-selected strategies, as suggested in this paper, can contribute to achieving sustainability. Acknowledging that not all strategies will be equally effective in all contexts, our framework offers a suite of approaches. The framework thus provides guidance within discourses on different meanings of sustainability goals and different means within an ecosystem service framework to achieve such goals. Such deliberations might help highlight interlinkages or trade-offs between sustainability strategies. For example, an explicit focus on both intragenerational justice for humans and interspecies justice might help bridge the divide between the original use of the ecosystem service concept as a communicative tool for biodiversity conservation and its more recent use as a management tool for increasing human well-being. In turn, societal deliberation on what is sufficient, rather than efficient, in the appropriation of ecosystem services may lead to new ways of thinking about our interactions with and dependence on the natural world.

\section{Conclusion}

The ecosystem service concept may involve normativity in recognition, valuation and conservation of ecosystems. This normative character needs navigation, conceptual reflection and transparency on how an operationalization of ecosystem services could contribute to sustainability. While the ecosystem service concept originated from a sustainability perspective, it has increasingly encompassed potentially unsustainable use of natural resources. Hence, the concept's openness to interpretation might obstruct its power to contribute to the overarching goal of sustainability. If the ecosystem service concept is understood as contributing to sustainability, ecosystem services need to be conceptualized through sustainability strategies rather than assessing all forms of natural resource use in aggregated, snap-shot assessments. We have distinguished seven strategies for sustainability. In relation to each of these strategies, we have suggested key issues that need to be considered in the application of the ecosystem service concept and the management of ecosystems. While not every piece of research can, or should, consider all of these issues, we believe greater focus on the sustainability strategies (as 'filters') would guide interpretation of the ecosystem service concept and hence reduce parts of its vagueness. The more 'filters' it passes, the more likely an operationalization of ecosystem services facilitates a contribution to sustainability. An enhanced and rich vision of ecosystem services that is in line with the aims of sustainability should thus include several dimensions of justice and be aligned with the suggested strategies to handle ecological limits.

\section{Acknowledgements}

We thank two reviewers and the Editor-in-Chief, Leon Braat, for constructive comments that helped to improve an earlier version of the manuscript. We thank Bas Amelung for fruitful discussions. A.v.O. acknowledges funding from STW, project number 12691 "Nature-driven nourishment of coastal systems (NatureCoast)".

\section{References}

Abson, D.J., Termansen, M., 2011. Valuing ecosystem services in terms of ecological risks and returns. Conserv. Biol. 25, 250-258.

Abson, D.J., von Wehrden, H., Baumgärtner, S., Fischer, J., Hanspach, J., Härdtle, W. Heinrichs, H., Klein, A.M., Lang, D.J., Martens, P., Walmsley, D., 2014. Ecosystem services as a boundary object for sustainability. Ecol. Econ. 103, 29-37.

Abson, D.J., Fischer, J., Leventon, J., Newig, J., Schomerus, T., Vilsmaier, U., von Wehrden, H., Abernethy, P., Ives, C.D., Jager, N.W., Lang, D.J., 2017. Leverage points for sustainability transformation. Ambio 46, 30-39.

Agyeman, J., Evans, B., 2004. 'Just sustainability': the emerging discourse of environmental justice in Britain? Geogr. J. 170, 155-164.

Alcott, B., 2005. Jevons' paradox. Ecol. Econ. 54, 9-21.

Aragão, A., Jacobs, S., Cliquet, A., 2016. What's law got to do with it? Why environmental justice is essential to ecosystem service valuation. Ecosyst. Serv. 22 (Part B), 221-227.

Baumgärtner, S., Glotzbach, S., Hoberg, N., Quaas, M.F., Stumpf, K.H., 2012. Economic analysis of trade-offs between justices. Intergen. Just Rev. 1 (2012), 4-9.

Benayas, J.M.R., Newton, A.C., Diaz, A., Bullock, J.M., 2009. Enhancement of biodiversity and ecosystem services by ecological restoration: a metaanalysis. Science $325,1121-1124$

Bennett, E.M., Peterson, G.D., Gordon, L.J., 2009. Understanding relationships among multiple ecosystem services. Ecol. Lett. 12, 1394-1404.

Bennett, E.M., Cramer, W., Begossi, A., Cundill, G., Díaz, S., Egoh, B.N., Geijzendorffer, I.R., Krug, C.B., Lavorel, S., Lazos, E., Lebel, L., Martín-López, B., Meyfroidt, P., Mooney, H.A., Nel, J.L., Pascual, U., Payet, K., Harguindeguy, N.P., Peterson, G.D. Prieur-Richard, A.-H., Reyers, B., Roebeling, P., Seppelt, R., Solan, M., Tschakert, P., Tscharntke, T., Turner Ii, B.L., Verburg, P.H., Viglizzo, E.F., White, P.C.L., Woodward, G., 2015. Linking biodiversity, ecosystem services, and human wellbeing: three challenges for designing research for sustainability. Curr. Opin. Environ. Sustainability 14, 76-85.

Berbés-Blázquez, M., González, J.A., Pascual, U., 2016. Towards an ecosystem services approach that addresses social power relations. Curr. Opin. Environ. Sustainability 19, 134-143.

Biggs, R., Schlüter, M., Biggs, D., Bohensky, E.L., BurnSilver, S., Cundill, G., Dakos, V., Daw, T.M., Evans, L.S., Kotschy, K., Leitch, A.M., Meek, C., Quinlan, A., RaudseppHearne, C., Robards, M.D., Schoon, M.L., Schultz, L., West, P.C., 2012. Toward principles for enhancing the resilience of ecosystem services. Ann. Rev. Environ. Resour. 37, 421-448.

Boyd, J., Banzhaf, S., 2007. What are ecosystem services? The need for standardized environmental accounting units. Ecol. Econ. 63, 616-626.

Burkhard, B., Kroll, F., Nedkov, S., Müller, F., 2012. Mapping ecosystem service supply, demand and budgets. Ecol. Ind. 21, 17-29.

Castro, A.J., Verburg, P.H., Martín-López, B., Garcia-Llorente, M., Cabello, J., Vaughn, C.C., López, E., 2014. Ecosystem service trade-offs from supply to social demand: a landscape-scale spatial analysis. Landscape Urban Plann. 132, 102-110.

Chan, K.M.A., Satterfield, T., Goldstein, J., 2012. Rethinking ecosystem services to better address and navigate cultural values. Ecol. Econ. 74, 8-18.

Chan, K.M.A., Balvanera, P., Benessaiah, K., Chapman, M., Díaz, S., Gómez-Baggethun, E., Gould, R., Hannahs, N., Jax, K., Klain, S., Luck, G.W., Martín-López, B., Muraca, B., Norton, B., Ott, K., Pascual, U., Satterfield, T., Tadaki, M., Taggart, J., Turner, N., 2016. Opinion: why protect nature? Rethinking values and the environment. Proc. Natl. Acad. Sci. 113, 1462-1465.

Costanza, R., 1989. What is ecological economics? Ecol. Econ. 1, 1-7.

Costanza, R., 2000. Social goals and the valuation of ecosystem services. Ecosystems 3, 4-10.

Daly, H.E., 1977. Steady-State Economics. Freeman and Company, San Francisco, W. H.

Daly, H.E., 1992. Allocation, distribution, and scale: towards an economics that is efficient, just, and sustainable. Ecol. Econ. 6, 185-193.

Danley, B., Widmark, C., 2016. Evaluating conceptual definitions of ecosystem services and their implications. Ecol. Econ. 126, 132-138.

Davidson, M.D., 2013. On the relation between ecosystem services, intrinsic value, existence value and economic valuation. Ecol. Econ. 95, 171-177. 
Daw, T., Brown, K., Rosendo, S., Pomeroy, R., 2011. Applying the ecosystem services concept to poverty alleviation: the need to disaggregate human well-being. Environ. Conserv. 38, 370-379.

Daw, T.M., Coulthard, S., Cheung, W.W.L., Brown, K., Abunge, C., Galafassi, D., Peterson, G.D., McClanahan, T.R., Omukoto, J.O., Munyi, L., 2015. Evaluating taboo trade-offs in ecosystems services and human well-being. Proc. Natl. Acad. Sci. U.S.A. 112, 6949-6954.

Díaz, S., Demissew, S., Carabias, J., Joly, C., Lonsdale, M., Ash, N., Larigauderie, A. Adhikari, J.R., Arico, S., Báldi, A., Bartuska, A., Baste, I.A., Bilgin, A., Brondizio, E. Chan, K.M.A., Figueroa, V.E., Duraiappah, A., Fischer, M., Hill, R., Koetz, T., Leadley, P., Lyver, P., Mace, G.M., Martin-Lopez, B., Okumura, M., Pacheco, D., Pascual, U., Pérez, E.S., Reyers, B., Roth, E., Saito, O., Scholes, R.J., Sharma, N., Tallis, H., Thaman, R., Watson, R., Yahara, T., Hamid, Z.A., Akosim, C., Al-Hafedh, Y., Allahverdiyev, R., Amankwah, E., Asah, S.T., Asfaw, Z., Bartus, G., Brooks, L.A., Caillaux, J., Dalle, G., Darnaedi, D., Driver, A., Erpul, G., Escobar-Eyzaguirre, P., Failler, P., Fouda, A.M.M., Fu, B., Gundimeda, H., Hashimoto, S., Homer, F. Lavorel, S., Lichtenstein, G., Mala, W.A., Mandivenyi, W., Matczak, P., Mbizvo, C., Mehrdadi, M., Metzger, J.P., Mikissa, J.B., Moller, H., Mooney, H.A., Mumby, P., Nagendra, H., Nesshover, C., Oteng-Yeboah, A.A., Pataki, G., Roué, M., Rubis, J., Schultz, M., Smith, P., Sumaila, R., Takeuchi, K., Thomas, S., Verma, M., YeoChang, Y., Zlatanova, D., 2015. The IPBES conceptual framework - connecting nature and people. Curr. Opin. Environ. Sustainability 14, 1-16.

Dislich, C., Keyel, A.C., Salecker, J., Kisel, Y., Meyer, K.M., Auliya, M., Barnes, A.D., Corre, M.D., Darras, K., Faust, H., Hess, B., Klasen, S., Knohl, A., Kreft, H., Meijide, A., Nurdiansyah, F., Otten, F., Pe'er, G., Steinebach, S., Tarigan, S., Tölle, M.H., Tscharntke, T., Wiegand, K., 2016. A review of the ecosystem functions in oil palm plantations, using forests as a reference system. Biol. Rev.

Duncker, P.S., Raulund-Rasmussen, K., Gundersen, P., Katzensteiner, K., De Jong, J., Ravn, H.P., Smith, M., Eckmüllner, O., Spiecker, H., 2012. How forest management affects ecosystem services, including timber production and economic return: synergies and trade-offs. Ecol. Soc. 17 (4), 50.

Ehrlich, P.R., Ehrlich, A., 1981. Extinction: The Causes and Consequences of the Disappearance of Species. Random House, New York.

Ehrlich, P.R., Mooney, H.A., 1983. Extinction, substitution, and ecosystem services. Bioscience 33, 248-254

Ekins, P., Simon, S., Deutsch, L., Folke, C., De Groot, R., 2003. A framework for the practical application of the concepts of critical natural capital and strong sustainability. Ecol. Econ. 44, 165-185.

Ernstson, H., 2013. The social production of ecosystem services: a framework for studying environmental justice and ecological complexity in urbanized landscapes. Landscape Urb. Plann. 109, 7-17.

Felipe-Lucia, M.R., Martín-López, B., Lavorel, S., Berraquero-Díaz, L., Escalera-Reyes, J., Comín, F.A., 2015. Ecosystem services flows: why stakeholders' power relationships matter. PLoS ONE 10, e0132232.

Fisher, B., Turner, K., Zylstra, M., Brouwer, R., de Groot, R., Farber, S., Ferraro, P., Green, R., Hadley, D., Harlow, J., Jefferiss, P., Kirkby, C., Morling, P., Mowatt, S. Naidoo, R., Paavola, J., Strassburg, B., Yu, D., Balmford, A., 2008. Ecosystem Services and economic theory: integration for policy-relevant research. Ecol. Appl. 18, 2050-2067.

Gómez-Baggethun, E., de Groot, R., Lomas, P.L., Montes, C., 2010. The history of ecosystem services in economic theory and practice: from early notions to markets and payment schemes. Ecol. Econ. 69, 1209-1218.

Haines-Young, R., Potschin, M., 2010a. Proposal for a Common International Classification of Ecosystem Goods and Services (CICES) for integrated environmental and economic accounting. Eur. Environ. Agency.

Haines-Young, R., Potschin, M., 2010b. The links between biodiversity, ecosystem services and human well-being. In: Raffaelli, D., Frid, C. (Eds.), Ecosystem Ecology: a new synthesis. Cambridge University Press, Cambridge, pp. 110-139.

Haines-Young, R., Potschin, M., 2013. Common International Classification of Ecosystem Services (CICES): Consultation on Version 4, August-December 2012. Access through www.cices.eu.

Halpern, B.S., Walbridge, S., Selkoe, K.A., Kappel, C.V., Micheli, F., D’Agrosa, C., Bruno, J.F., Casey, K.S., Ebert, C., Fox, H.E., Fujita, R., Heinemann, D., Lenihan, H.S., Madin, E.M.P., Perry, M.T., Selig, E.R., Spalding, M., Steneck, R., Watson, R., 2008. A global map of human impact on marine ecosystems. Science 319, 948-952.

Iniesta-Arandia, I., García-Llorente, M., Aguilera, P.A., Montes, C., Martín-López, B., 2014. Socio-cultural valuation of ecosystem services: uncovering the links between values, drivers of change, and human well-being. Ecol. Econ. 108, $36-$ 48.

Jacobs, S., Dendoncker, N., Keune, H., 2013. Editorial for Ecosystem Services - Global Issues, Local Practices: No Root, No Fruit-Sustainability and Ecosystem Services. In: Jacobs, S., Dendoncker, N., Keune, H. (Eds.), Ecosystem Services. Global Issues, Local Practices. Elsevier, Oxford, pp. xix-xxviii.

Jacobs, S., Dendoncker, N., Martín-López, B., Barton, D.N., Gomez-Baggethun, E., Boeraeve, F., McGrath, F.L., Vierikko, K., Geneletti, D., Sevecke, Katharina J., Pipart, N., Primmer, E., Mederly, P., Schmidt, S., Aragão, A., Baral, H., Bark, Rosalind H., Briceno, T., Brogna, D., Cabral, P., De Vreese, R., Liquete, C., Mueller, H., Peh, K.S.H., Phelan, A., Rincón, Alexander R., Rogers, S.H., Turkelboom, F., Van Reeth, W., van Zanten, B.T., Wam, H.K., Washbourn, C.-L., 2016. A new valuation school: Integrating diverse values of nature in resource and land use decisions. Ecosyst. Serv. 22 (Part B), 213-220.

Justus, J., Colyvan, M., Regan, H., Maguire, L., 2009. Buying into conservation: intrinsic versus instrumental value. Trends Ecol. Evol. 24, 187-191.

Kissinger, M., Rees, W.E., Timmer, V., 2011. Interregional sustainability: governance and policy in an ecologically interdependent world. Environ. Sci. Policy 14, 965976.
Klain, S.C., Satterfield, T.A., Chan, K.M.A., 2014. What matters and why? Ecosystem services and their bundled qualities. Ecol. Econ. 107, 310-320.

Kosoy, N., Corbera, E., 2010. Payments for ecosystem services as commodity fetishism. Ecol. Econ. 69, 1228-1236.

Kuhlman, T., Farrington, J., 2010. What is sustainability? Sustainability 2, 3436 3448.

Lakerveld, R.P., Lele, S., Crane, T.A., Fortuin, K.P.J., Springate-Baginski, O., 2015. The social distribution of provisioning forest ecosystem services: evidence and insights from Odisha, India. Ecosyst. Serv. 14, 56-66.

Lautenbach, S., Mupepele, A.-C., Dormann, C.F., Lee, H., Schmidt, S., Scholte, S.S.K., Seppelt, R., van Teeffelen, A.J.A., Verhagen, W., Volk, M., 2015. Blind spots in ecosystem services research and implementation. bioRxiv.

Lee, H., Lautenbach, S., 2016. A quantitative review of relationships between ecosystem services. Ecol. Indic. 66, 340-351.

Liquete, C., Piroddi, C., Drakou, E.G., Gurney, L., Katsanevakis, S., Charef, A., Egoh, B. 2013. Current status and future prospects for the assessment of marine and coastal ecosystem services: a systematic review. PLoS ONE 8, e67737.

Liu, J., Mooney, H., Hull, V., Davis, S.J., Gaskell, J., Hertel, T., Lubchenco, J., Seto, K.C. Gleick, P., Kremen, C., Li, S., 2015. Systems integration for global sustainability. Science 347, 1258832.

Liu, J., Yang, W., Li, S., 2016. Framing ecosystem services in the telecoupled Anthropocene. Front. Ecol. Environ. 14, 27-36.

Lockwood, M., 1999. Humans valuing nature: synthesising insights from philosophy, psychology and economics. Environ. Values 8, 381-401.

Loos, J., Abson, D.J., Chappell, M.J., Hanspach, J., Mikulcak, F., Tichit, M., Fischer, J. 2014. Putting meaning back into "sustainable intensification". Front. Ecol. Environ. 12, 356-361.

Louv, R., 2005. Last Child in the Woods: Saving Our Children From Nature-Deficit Disorder. Algonquin Books, Chapel Hill.

MA, Millennium Ecosystem Assessment, 2005. Ecosystems and Human Well-Being: Synthesis report. Island Press, Washington D.C.

Malinga, R., Gordon, L.J., Jewitt, G., Lindborg, R., 2015. Mapping ecosystem services across scales and continents - a review. Ecosyst. Serv. 13, 57-63.

McDermott, M., Mahanty, S., Schreckenberg, K., 2013. Examining equity: a multidimensional framework for assessing equity in payments for ecosystem services. Environ. Sci. Policy 33, 416-427.

Milcu, A.I., Sherren, K., Hanspach, J., Abson, D., Fischer, J., 2014. Navigating conflicting landscape aspirations: application of a photo-based Q-method in Transylvania (Central Romania). Land Use Policy 41, 408-422.

Miller, J.R., 2005. Biodiversity conservation and the extinction of experience. Trends Ecol. Evol. 20, 430-434.

Moldan, B., Janoušková, S., Hák, T., 2012. How to understand and measure environmental sustainability: indicators and targets. Ecol. Indic. 17, 4-13.

Naeem, S., Chazdon, R., Duffy, J.E., Prager, C., Worm, B., 2016. Biodiversity and human well-being: an essential link for sustainable development. Proc. R. Soc. B: Biol. Sci. 283.

Nahlik, A.M., Kentula, M.E., Fennessy, M.S., Landers, D.H., 2012. Where is the consensus? A proposed foundation for moving ecosystem service concepts into practice. Ecol. Econ. 77, 27-35.

Neumayer, E., 2010. Weak Versus Strong Sustainability - Exploring the Limits of Two Opposing Paradigms. Edward Elgar, Cheltenham, UK, Northhampton, MA, USA.

Norgaard, R.B., 2010. Ecosystem services: from eye-opening metaphor to complexity blinder. Ecol. Econ. 69, 1219-1227.

Norton, B.G., 2005. Sustainability: A Philosophy of Adaptive Ecosystem Management. University of Chicago Press, Chicago.

Ott, K., 2003. The case for strong sustainability. In: Ott, K., Thapa, P.P. (Eds.) Greifswald's Environmental Ethics. Steinbecker Verlag Rose, Greifswald, pp. 5964.

Palomo, I., Felipe-Lucia, M.R., Bennett, E.M., Martín-López, B., Pascual, U., 2016 Chapter six - disentangling the pathways and effects of ecosystem service coproduction. In: Guy, W., David, A.B. (Eds.), Adv. Ecol. Res.. Academic Press, pp. 245-283.

Pauly, D., Christensen, V., Dalsgaard, J., Froese, R., Torres, F., 1998. Fishing down marine food webs. Science 279, 860-863.

Piso, Z., Werkheiser, I., Noll, S., Leshko, C., 2016. Sustainability of what? Recognising the diverse values that sustainable agriculture works to sustain. Environ. Values 25, 195-214.

Potschin, M., Haines-Young, R., 2013. Landscapes, sustainability and the placebased analysis of ecosystem services. Landscape Ecol. 28, 1053-1065.

Power, A.G., 2010. Ecosystem services and agriculture: tradeoffs and synergies. Philos. Trans. R. Soc. B: Biol. Sci. 365, 2959-2971.

Raudsepp-Hearne, C., Peterson, G.D., Bennett, E.M., 2010. Ecosystem service bundles for analyzing tradeoffs in diverse landscapes. Proc. Natl. Acad. Sci. U.S.A. 107, $5242-5247$.

Raymond, C.M., Singh, G.G., Benessaiah, K., Bernhardt, J.R., Levine, J., Nelson, H., Turner, N.J., Norton, B., Tam, J., Chan, K.M.A., 2013. Ecosystem services and beyond: using multiple metaphors to understand human-environment relationships. Bioscience 63, 536-546.

Remme, R.P., Schröter, M., Hein, L., 2014. Developing spatial biophysical accounting for multiple ecosystem services. Ecosyst. Serv. 10, 6-18.

Sachs, W., Santarius, T., 2007. Fair future: resource conflicts, security, and global justice. Zed Books, London, UK.

Schlosberg, D., 2004. Reconceiving environmental justice: global movements and political theories. Environ. Politics 13, 517-540. 
Schmidt, K., Sachse, R., Walz, A., 2016. Current role of social benefits in ecosystem service assessments. Landscape Urb. Plann. 149, 49-64.

Schröter, M., Barton, D.N., Remme, R.P., Hein, L., 2014a. Accounting for capacity and flow of ecosystem services: a conceptual model and a case study for Telemark, Norway. Ecol. Ind. 36, 539-551.

Schröter, M., van der Zanden, E.H., van Oudenhoven, A.P.E., Remme, R.P., SernaChavez, H.M., de Groot, R.S., Opdam, P., 2014b. Ecosystem services as a contested concept: a synthesis of critique and counter-arguments. Conserv. Lett. 7, 514-523.

Sikor, T., Fisher, J., Few, R., Martin, A., Zeitoun, M., 2013. The justices and injustices of ecosystem services. In: Sikor, T. (Ed.), The Justices and Injustices of Ecosystems Services. Routledge, pp. 187-200.

Smith, L.M., Case, J.L., Smith, H.M., Harwell, L.C., Summers, J.K., 2013. Relating ecosystem services to domains of human well-being: foundation for a U.S index. Ecol. Indic. 28, 79-90.

Steffen, W., Richardson, K., Rockström, J., Cornell, S.E., Fetzer, I., Bennett, E.M., Biggs, R., Carpenter, S.R., de Vries, W., de Wit, C.A., Folke, C., Gerten, D., Heinke, J. Mace, G.M., Persson, L.M., Ramanathan, V., Reyers, B., Sörlin, S., 2015. Planetary boundaries: guiding human development on a changing planet. Science 347, 1259855.

TEEB, 2010. The Economics of Ecosystems and Biodiversity: Ecological and Economic Foundations. Earthscan, London and Washington.

UK NEA, 2011. The UK National Ecosystem Assessment: Synthesis of the Key Findings. UNEP-WCMC, Cambridge.

UN, 2012. The Future we Want. Resolution 66/288, adopted by the General Assembly.
UNEP, 2010. The Strategic Plan for Biodiversity 2011-2020 and the Aichi Biodiversity Targets. Decision UNEP/CBD $/ \mathrm{COP} / \mathrm{DEC} / \mathrm{X} / 2$, adopted by the Conference of the Parties to the Convention on Biological Diversity.

van den Belt, M., Stevens, S.M., 2016. Transformative agenda, or lost in the translation? A review of top-cited articles in the first four years of Ecosystem Services. Ecosyst. Serv. 22 (Part A), 60-72.

van Oudenhoven, A.P.E., Petz, K., Alkemade, R., Hein, L., de Groot, R.S., 2012. Framework for systematic indicator selection to assess effects of land management on ecosystem services. Ecol. Indic. 21, 110-122.

van Oudenhoven, A.P.E., Siahainenia, A.J., Sualia, I., Tonneijck, F.H., van der Ploeg, S., de Groot, R.S., Alkemade, R., Leemans, R., 2015. Effects of different management regimes on mangrove ecosystem services in Java, Indonesia. Ocean Coast. Manag. 116, 353-367.

Villamagna, A.M., Angermeier, P.L., Bennett, E.M., 2013. Capacity, pressure, demand, and flow: a conceptual framework for analyzing ecosystem service provision and delivery. Ecol. Complex. 15, 114-121.

Walker, B.H., Gunderson, L.H., Kinzig, A.P., Folke, C., Carpenter, S.R., Schultz, L., 2006. A handful of heuristics and some propositions for understanding resilience in social-ecological systems. Ecol. Soc. 11, 13.

WCED, World Commission on Environment and Development, 1987. Our common future. Oxford University Press, Oxford.

Wilson, M.A., Howarth, R.B., 2002. Discourse-based valuation of ecosystem services: establishing fair outcomes through group deliberation. Ecol. Econ. 41, 431-443.

Wu, J., 2013. Landscape sustainability science: ecosystem services and human wellbeing in changing landscapes. Landscape Ecol. 28, 999-1023. 